\title{
Correlated responses and genetic parameters for performance and carcass traits in a broiler line
}

\author{
Respostas correlacionadas e parâmetros genéticos para características de desempenho \\ e de carcaça em uma linha de frangos de corte
}

\author{
PERTILE, Simone Fernanda Nedel ${ }^{1}$; ZAMPAR, Aline ${ }^{1}$; PETRINI, Juliana ${ }^{1}$; GAYA, \\ Leila de Genova ${ }^{2}$; ROVADOSCKI, Gregori Alberto ${ }^{1}$; RAMÍREZ-DÍAZ, Johanna ${ }^{1}$; \\ FERRAZ, José Bento Sterman ${ }^{3}$; MICHELAN FILHO, Tércio ${ }^{4}$; MOURÃO, Gerson \\ Barreto $^{1 *}$
}

\author{
${ }^{1}$ Universidade de São Paulo, Escola Superior de Agricultura Luiz de Queiroz, Departamento de \\ Zootecnia, Piracicaba, São Paulo, Brasil. \\ ${ }^{2}$ Universidade Federal de São João del-Rei, Departamento de Engenharia de Biossistemas, São João del- \\ Rei, Minas Gerais, Brasil. \\ ${ }^{3}$ Universidade de São Paulo, Faculdade de Zootecnia e Engenharia de Alimentos, Departamento de \\ Ciências Básicas, Pirassununga, São Paulo, Brasil. \\ ${ }^{4}$ Aviagen America Latina Ltda, Rio Claro, São Paulo, Brasil. \\ *Endereço para correspondência: gbmourao@usp.br.
}

\section{SUMMARY}

The growth rate of broilers has triplicated in the last decades. The body weight is used as one of the selection criteria whereas the carcass traits are valuable market requirements. Thus, the meat industry like animals with high weights at slaughter and better carcass traits. However, the genetic relation of carcass traits with several body weights is unknown. Therefore, we established genetic associations among performance and carcass traits in a broiler chicken line and estimated genetic gain and trends. We also evaluated what age of selection would lead to a more efficient indirect selection of carcass traits. The data set with information of weights in different ages and carcass traits of 128,459 chickens was used. The pedigree data used contained 132,442 chickens. Genetic analysis were realized using ASREML $^{\circledR}$ software applied a restricted maximum likelihood method. Heritability estimates ranged from moderate to high, which indicates that these traits can have high selection response. Genetic correlations between performance and carcass traits varied from moderate to high, which indicates the presence of a genetic association whereas genetic trends indicated that direct selection is occurring for body weight at different ages. Theselection at 30 and 38 days should be considered instead of the slaughter weight, as it anticipates selection in around 12 days.

Keywords: body weight, chicken, genetic trend, heritability, variance components

\section{RESUMO}

A taxa de crescimento de frangos de corte foi triplicada nas últimas décadas. $\mathrm{O}$ peso corporal é utilizado como um dos principais critérios de seleção, enquanto que as características de carcaça são essenciais para o mercado. Assim, a indústria avícola busca animais com pesos altos ao abate e excelentes características de carcaça. Contudo, a associação genética entre as características de carcaça e desempenho é desconhecida. Deste modo, foram estabelecidas associações genéticas entre estas características, além das estimativas do progresso genético e as tendências genéticas para uma linhagem comercial de frango de corte. Avaliou-se a idade ideal para a seleção indireta, visando a melhoraria das características de carcaça. Foram utilizadas informações de pesos em diferentes idades e características de carcaça de 128.459 frangos em diferentes idades ao passo que o pedigree dispunha de 132.442 aves. As análises 
genéticas foram realizadas por meio do software ASReml®, utilizando o método da máxima verossimilhança restrita, sob o modelo animal. As estimativas de herdabilidade variaram de moderadas a altas, sendo indicativo de que estas características podem ter alta resposta à seleção. As correlações genéticas entre as características de desempenho e carcaça variaram de moderadas a altas, indicando a presença de associação genética, ao passo que as tendências genéticas sugerem que a seleção direta está ocorrendo para o peso corporal em diferentes idades. A seleção nas idades 30 e 38 dias deve ser considerada em vez do peso ao abate, uma vez que antecipa a seleção em um período aproximado de 12 dias.

Palavras-chave: componentes de variância, frangos de corte, herdabilidade, peso corporal, tendência genética

\section{INTRODUCTION}

Brazil has been the first exporter and the third largest producer of broilers in the world, with a production of over 12 million tons of chicken meat (UBA, 2011). Over the last four decades, selection of broilers aimed to increase growth rates, which then led to higher productivity levels. The growth rate of broilers triplicated, which reverted into broilers being slaughtering one day earlier than before, for each selection year (HAVENSTEIN et al., 2003). The carcass quality traits have been incorporated as an important selection objective and the body weight is used as one of the selection criteria. Thus, the meat industry like animals with high weights at slaughter and better carcass traits.

Genetic relations for some growth and carcass traits have been previously studied (Le BIHAN-DUVAL et al., 1998; Le BIHAN-DUVAL et al., 2001; RANCE et al., 2002; ZEREHDARAN et al., 2004; GAYA et al., 2006; VAYEGO et al., 2008; GROSSO et al., 2009). Although these studies had considered the carcass traits, the genetic relation between carcass traits with body weights were not analyzed, these may limit our understanding on how the animal performance affects carcass traits. Additionally, the use of slaughter weight as the only selection criterion to improve carcass traits can be biased.

Although most chicken lines are highyield, exist differences among lines due to the selection pressure of breeding programs. Thus, the yield of carcasses and marketable parts varies within the same line, depending on age and body weight of the animal. Consequently, we aimed to estimate genetics parameters, trends and establish the genetic associations among performance and carcass traits in a broiler chicken line, to understand the growth influence on the carcass traits.

\section{MATERIAL AND METHODS}

The records of 128,459 of a commercial line of broiler chicken containing information on pedigree, performance, carcass and animal management were analyzed. The data were collected from an elite flock using the sib test program. The body weight (BW) was measured at 7 (BW7), 30 (BW30) and 38 days (BW38) of age and before slaughter (SW) with approximately 41 to 45 days of age.

For carcass traits, after the slaughter we measured the hot carcass weight $(\mathrm{CW})$ without viscera, neck, feet and abdominal fat. The bone and skin was removed to determine the breast weight (BRW). BRW and leg weight (LW) were recorded after carcass cooling. The relative weights of carcass (CY), breast (BRY) and legs (LY) were calculated as the ratio between the absolute weight and the slaughter weight for each trait. 
Genetic analyses were carried out with model that included flock, parents mating group, gender, and the interaction between flock and gender as fixed effects for BW7, BW30, BW38, SW, CW, BRW, LW, CY and LY.

The model for BRY considered parents mating group, gender, and month of slaughter as fixed effects and age of slaughter, maternal age at birth and the interactions between gender and month of slaughter, gender and age of slaughter, and gender and maternal age at birth were considered as covariates.

Descriptive statistics were calculated by PROC MEANS of SAS $^{\circledR}$ software. (Co)variance component estimates and genetic parameters were obtained by restricted maximum likelihood using the software ASREML ${ }^{\circledR}$ (GILMOUR et al., 2009). The relationship matrix was composed of 132,442 birds, with 666 sires and 5,452 dams. The model used in the single trait analysis was $y=X b+Z u+e$, where $y$ is the dependent variables vector; $X$ is the fixed effects incidence matrix, associating elements from $b$ to $y ; b$ is the fixed effects vector; $Z$ is the random effects incidence matrix, associating elements from $u$ to $y$; $u$ is a vector of random additive genetic effects; and $e$ is the residual effects vector, NID $(0, \sigma$ ${ }^{2}$ ). The model used in the two-trait analysis was:

$\left[\begin{array}{l}y_{1} \\ y_{2}\end{array}\right]=\left[\begin{array}{cc}X_{1} & 0 \\ 0 & X_{2}\end{array}\right]\left[\begin{array}{l}b_{1} \\ b_{2}\end{array}\right]+\left[\begin{array}{cc}Z_{1} & 0 \\ 0 & Z_{2}\end{array}\right]\left[\begin{array}{l}u_{1} \\ u_{2}\end{array}\right]+\left[\begin{array}{l}e_{1} \\ e_{2}\end{array}\right]$ where $y_{1}$ and $y_{2}$ are vectors of two different traits. The vectors of fixed effects for trait $1\left(b_{1}\right)$ and trait $2\left(b_{2}\right)$ are the same as described in the single trait model. The vectors $u_{1}$ and $u_{2}$ are random additive genetic effects, and $e_{1}$ and $e_{2}$ are residual effects for trait 1 and trait 2 , respectively. The incidence matrices $X_{1}$ and $X_{2}$ associates elements of $b_{1}$ and $b_{2}$ with the records in $y_{1}$ and $y_{2}$.
Genetic trends were estimated by regression of breeding values of birds in six generations of selection, using the PROC REG of $\mathrm{SAS}^{\circledR}$ software. The potential genetics gain were calculated according to: $\Delta G=i \sigma_{p} h^{2}$ where: $\Delta G$ =genetic gain for generation of selection; $i=$ selection intensity $\left(i_{m}=2,27\right.$ and $\left.i_{f}=1,76\right)$, considering that $3 \%$ of males and $10 \%$ of females were selected for reproduction, similarity as in Zerehdaran et al., 2005; $\sigma_{p}=$ phenotypic standard deviation; $h^{2}=$ heritability. The correlated responses were calculated as: $C R_{y}=i_{X} h_{X} r_{g X} \sigma_{g Y} \quad$, where: $C R_{\mathrm{y}}=$ correlated response in the trait $\mathrm{Y}$; $i_{X}=$ selection intensity $\left(i_{X m}=2,27\right.$ and $\left.i_{X f}=1,76\right) ; h_{X}=$ square root of the heritability of trait $\mathrm{X} ; \boldsymbol{r}_{g X Y}=$ genetic correlation between the traits X e Y; $\sigma_{g Y}$ genetic standard deviation of the trait $\mathrm{Y}$.

\section{RESULTS AND DISCUSSION}

The performance traits considered were body weight at 7 (BW7), 30 (BW30), and 38 days (BW38) and the slaughter weight. Carcass traits were the weights of carcass (CW), breast (BRW), and legs (LW), and relative weights of carcass (CY), breast (BRY) and legs (LY) (Table 1).

Our results were similar to those found by Gaya et al. (2006) and Grosso et al. (2009). The coefficients of variation ranged from $10 \%$ to $17 \%$ for most traits, which indicates the variability in the population for the studied traits. However, the carcass traits in our study (i.e. CY, BRY and LY) presented low variation coefficients probably due to selection of animals at slaughter. Nevertheless, low coefficients of variation for $\mathrm{CY}$ were also found by N'Dri et al. (2006) and Grosso et al. 
(2009), which reported values of 5\% and $2.62 \%$, respectively. The mean for $\mathrm{CW}$, BRW, and LW was similar to Grosso et al. (2009), and higher than those presented by Rance et al. (2002), Zerehdaran et al. (2004), Gaya et al. (2006) and N'Dri et al.(2006). These differences are related with management system. In others studies the population was characterized by the slow growth rate and consequently the animals were slaughtered at 74 days of age (N'DRI et al. 2006). Differences in growth, carcass and meat-quality traits among genotypes were also presented by Yang \& Jiang (2005) and Fanatico et al. (2007).

Table 1. Number of observations (n), maximum (MAX) and minimum (MIN) values, mean and standard deviation (SD) for body weight and carcass traits in a commercial line of broiler chicken

\begin{tabular}{lcccc}
\hline Trait & $\mathrm{N}$ & MIN & MAX & Mean \pm SD \\
\hline BW7 (g) & 69,011 & 132 & 295 & $213 \pm 29$ \\
BW30 (g) & 40,976 & 1080 & 1800 & $1452 \pm 145$ \\
BW38 (g) & 42,951 & 1440 & 2910 & $2189 \pm 280$ \\
SW (g) & 24,202 & 1616 & 3878 & $2742 \pm 388$ \\
CW (g) & 24,046 & 1116 & 2764 & $1935 \pm 284$ \\
BRW (g) & 23,465 & 264 & 798 & $534 \pm 93$ \\
LW (g) & 23,532 & 335 & 994 & $671 \pm 113$ \\
CY & 16,061 & 0.69 & 0.72 & $0.71 \pm 0.01$ \\
BRY & 23,495 & 0.10 & 0.24 & $0.20 \pm 0.02$ \\
LY & 19,333 & 0.20 & 0.26 & $0.24 \pm 0.01$ \\
\hline BW7 & & & &
\end{tabular}

BW7 = weight at seven days of age; BW30 = weight at 30 days of age; BW38 = weight at 38 days of age; $\mathrm{SW}=$ slaughter weight; $\mathrm{CW}=$ carcass weight; $\mathrm{BRW}=$ breast weight; $\mathrm{LW}=$ legs weight; $\mathrm{CY}=$ carcass yield; $B R Y=$ breast yield relative to slaughter weight; $L Y=$ legs weight relative to slaughter weight.

Moderate and high heritability coefficients were estimated for weight traits, which ranged from 0.23 to 0.64 (Table 2). Similar results were found by Gaya et al. (2006) for weight at 38 days of age (0.44) and slaughter weight (0.23). Rance et al. (2002) determined a higher heritability for slaughter weight (0.52). However, these authors considered a reduced data set if compared to our study. The heritability estimates in our study varied according to the age of the animal.

Carlborg et al. (2003), in a study involving QTL(quantitative trait loci) related to growth in chicken, observed that very few loci affected the entire growth process, which indicates that early and late growth are regulated by different genetic mechanisms. This fact was also identified by Sewalem et al. (2002) who suggested that the genes involved in the early growth are related to the development of digestive organs or skeletal growth while another set of genes is responsible for the growth of the muscle tissue, later in the bird life. Because the genetic control of growth varies through the animal life, it is expected that the estimates of heritability will also change as the animal age. Although the heritability for body weight tends to be higher at younger ages, the selective potentials did not follow this trend and increased with age. However, this probably 
occurred due to weight variation at distinct ages. Thus, when selective potentials were averaged to eliminate scale effects, the higher genetic gain was obtained for the weight at seven days, and decreased as the animal aged and reached slaughter age. This suggests that the weight at seven days has a greater selection response than the weight at older ages.

The estimates obtained for performance and carcass traits were moderate to high (Table 2), similar to the results presented in other studies (Le BIHANDUVAL et al., 2001; GAYA et al., 2006; N'DRI et al., 2006; GROSSO et al., 2009). BRW and BRY were associated to the highest values of performance and carcass traits and presented the highest potential genetic gains. This was expected, as the genetic gain estimation depends on the heritability. CY presented low heritability and, consequently lowest genetic gain. Besides the genetic factors, carcass yield can be also affected by nutrition, gender, slaughter weight, carcass composition and slaughter and chilling procedures (LÓPEZ et al., 2011). Rance et al. (2002) showed higher heritability estimates for CW and LW. For BRW, the heritability was similar to that estimated by Grosso et al. (2010).

Table 2. Estimates of variance components, heritability and selection potentials for body weight and carcass traits in a commercial line of broiler chicken

\begin{tabular}{lcccccc}
\hline Trait & $\boldsymbol{\sigma}_{a}^{2}$ & $\boldsymbol{\sigma}_{\varepsilon}^{2}$ & $\boldsymbol{\sigma}_{\boldsymbol{p}}^{2}$ & $\boldsymbol{h}^{2}(\mathrm{SE})$ & $\Delta G$ & $\Delta G(\%)$ \\
\hline BW7 (g) & 261.219 & 144.15 & 405.37 & $0.64(0.010)$ & 25.96 & 12.18 \\
BW30 (g) & $9,557.38$ & $6,773.73$ & $16,331.11$ & $0.58(0.017)$ & 149.35 & 10.28 \\
BW38 (g) & $19,961.4$ & $25,210.10$ & $45,171.50$ & $0.44(0.015)$ & 188.43 & 8.60 \\
SW (g) & $10,405.8$ & $35,181.40$ & $45,587.20$ & $0.23(0.016)$ & 98.95 & 3.60 \\
CW(g) & $6,435.12$ & $19,452.00$ & $25,887.12$ & $0.25(0.016)$ & 81.05 & 4.18 \\
BRW (g) & $1,279.9$ & $1,922.29$ & $3,202.19$ & $0.40(0.019)$ & 45.60 & 8.54 \\
LW (g) & $1,151.47$ & $2,580.04$ & $3,731.51$ & $0.31(0.017)$ & 38.15 & 5.68 \\
CY & 0.0000125 & 0.0000548 & 0.0000673 & $0.19(0.016)$ & 0.0031 & 0.44 \\
BRY & 0.0001071 & 0.0000877 & 0.0001948 & $0.55(0.020)$ & 0.0155 & 7.73 \\
LY & 0.0000275 & 0.0000405 & 0.0000681 & $0.40(0.019)$ & 0.0066 & 2.77 \\
\hline
\end{tabular}

$\sigma_{\mathrm{a}}^{2}=$ additive genetic variance; $\sigma_{\mathrm{e}}^{2}=$ residual variance; $\sigma_{\mathrm{p}}^{2}=$ phenotypic variance; $\mathrm{h}^{2}(\mathrm{SE})=$ heritability and respective standard error; $\Delta \mathrm{G}=$ selection potential; $\Delta \mathrm{G}(\%)=(\Delta \mathrm{G} / \mathrm{mean}) * 100 ; \mathrm{BW} 7=$ weight at seven days of age; $\mathrm{BW} 30=$ weight at 30 days of age; $\mathrm{BW} 38=$ weight at 38 days of age; $\mathrm{SW}=$ slaughter weight; $\mathrm{CW}=$ carcass weight; $\mathrm{BRW}=$ breast weight; $\mathrm{LW}=$ legs weight; $\mathrm{CY}=$ carcass yield; $\mathrm{BRY}=$ breast yield relative to slaughter weight; $\mathrm{LY}=$ legs yield relative to slaughter weight.

The genetic correlations of performance and carcass trait are presented in Table 3. Estimates were high and positive and ranged from 0.64 to 0.97 among live weights in different ages. Between BW7 and other traits of body weight the correlations were high; however, the genetic association is greater when the body weight was compared between less distant time points. These results agree with Carlborg et al. (2003) that reported differences in genetic control according to age.

The genetic correlation between $\mathrm{CW}$ and BRW (0.72) and between CW and LW (0.82) were high, indicating the 
possibility of indirect selection of BRW and LW using $\mathrm{CW}$ as selection criterion. Similar estimates for these traits were obtained by Gaya et al. (2006) and Rance et al. (2002). Between BRW and LW (0.27), genetic correlation was positive and moderate suggesting a genetic association between these traits. This result differs from that obtained by Gaya et al. (2006), which reported a genetic correlation estimate of -0.18 between
BRW and LW. The traits CW and CY; BRW and BRY; LW and LY presented high and positive genetic correlation, indicating that the indirect selection of relative weight is efficient when live weight is used as selection criterion. The genetic correlation between BRW and LY was moderate and negative, as well genetic correlation between BRY and LY. These traits were inversely associated, and should be carefully analyzed within breeding programs.

Table 3. Genetic (above diagonal) and phenotypic (below diagonal)correlations estimates for performance and carcass traits ${ }^{\mathrm{a}}$ in a commercial line of broiler chicken

\begin{tabular}{lcccccccccc}
\hline Trait & BW7 & BW30 & BW3 & SW & CW & BRW & LW & CY & BRY & LY \\
\hline \multirow{2}{*}{ BW7 } & - & 0.74 & 0.67 & 0.47 & 0.42 & 0.32 & 0.32 & -0.05 & 0.05 & -0.08 \\
& & $(0.013)$ & $(0.019)$ & $(0.031)$ & $(0.031)$ & $(0.030)$ & $(0.032)$ & $(0.051)$ & $(0.031)$ & $(0.038)$ \\
BW30 & 0.63 & & 0.64 & 0.89 & 0.85 & 0.65 & 0.70 & 0.08 & 0.11 & -0.08 \\
& $(0.005)$ & - & $(0.056)$ & $(0.014)$ & $(0.016)$ & $(0.025)$ & $(0.025)$ & $(0.066)$ & $(0.041)$ & $(0.053)$ \\
BW38 & 0.58 & 0.33 & - & 0.97 & 0.95 & 0.73 & 0.86 & 0.15 & 0.03 & 0.05 \\
& $(0.006)$ & $(0.030)$ & - & $(0.004)$ & $(0.005)$ & $(0.017)$ & $(0.012)$ & $(0.056)$ & $(0.037)$ & $(0.040)$ \\
SW & 0.34 & 0.72 & 0.91 & & 0.96 & 0.58 & 0.81 & 0.15 & -0.01 & 0.09 \\
& $(0.008)$ & $(0.005)$ & $(0.002)$ & - & $(0.004)$ & $(0.028)$ & $(0.016)$ & $(0.059)$ & $(0.043)$ & $(0.047)$ \\
CW & 0.33 & 0.73 & 0.90 & 0.96 & - & 0.72 & 0.82 & 0.47 & 0.18 & 0.17 \\
& $(0.008)$ & $(0.005)$ & $(0.002)$ & $(0.001)$ & - & $(0.020)$ & $(0.014)$ & $(0.047)$ & $(0.041)$ & $(0.045)$ \\
BRW & 0.31 & 0.64 & 0.78 & 0.77 & 0.84 & - & 0.27 & 0.60 & 0.82 & -0.31 \\
& $(0.009)$ & $(0.007)$ & $(0.004)$ & $(0.004)$ & $(0.003)$ & - & $(0.039)$ & $(0.036)$ & $(0.015)$ & $(0.039)$ \\
LW & 0.27 & 0.60 & 0.82 & 0.88 & 0.89 & 0.63 & & 0.29 & -0.26 & 0.66 \\
& $(0.009)$ & $(0.008)$ & $(0.003)$ & $(0.002)$ & $(0.002)$ & $(0.006)$ & - & $(0.052)$ & $(0.039)$ & $(0.028)$ \\
CY & 0.05 & 0.13 & 0.18 & 0.13 & 0.31 & 0.36 & 0.20 & - & 0.61 & 0.27 \\
& $(0.012)$ & $(0.015)$ & $(0.013)$ & $(0.009)$ & $(0.008)$ & $(0.008)$ & $(0.009)$ & - & $(0.031)$ & $(0.051)$ \\
BRY & 0.11 & 0.18 & 0.18 & 0.11 & 0.24 & 0.71 & 0.00 & 0.45 & - & -0.43 \\
& $(0.011)$ & $(0.014)$ & $(0.012)$ & $(0.009)$ & $(0.008)$ & $(0.004)$ & $(0.009)$ & $(0.008)$ & - & $(0.032)$ \\
LY & -0.04 & -0.03 & 0.04 & 0.11 & 0.17 & -0.06 & 0.51 & 0.16 & -0.23 & - \\
& $(0.012)$ & $(0.016)$ & $(0.010)$ & $(0.009)$ & $(0.008)$ & $(0.009)$ & $(0.007)$ & $(0.010)$ & $(0.009)$ & - \\
\hline
\end{tabular}

Standard errors in parenthesis. BW7 $=$ weight at seven days of age; BW30 = weight at 30 days of age; BW38 = weight at 38 days of age; $\mathrm{SW}=$ slaughter weight; $\mathrm{CW}=$ carcass weight; $\mathrm{BRW}=$ breast weight; $\mathrm{LW}=$ legs weight; $\mathrm{CY}=$ carcass yield; $\mathrm{BRY}=$ percentage of breast weight relative to slaughter weight; $\mathrm{LY}=$ percentage of legs weight relative to slaughter weight.

Estimates of genetic correlation among BW7 and the traits CW, BRW, and LW were lower than the estimates obtained with BW30, BW38, and SW (Table 3). Therefore, the indirect selection for increasing $\mathrm{CW}, \mathrm{BRW}$, and $\mathrm{LW}$ is more efficient when using BW30, BW38 or SW than BW7. Body weight is a trait of great economic relevance because of its direct relation with the efficiency of production and its correlation with such traits as the weight of specific sections of the carcass. Also, it is easily measured and can be obtained from animals at any age. 
The traits CY and BW7 and CY and BW30 presented a low genetic correlation, indicating a weak genetic association between them. However, the genetic correlation estimates between $\mathrm{CY}$ and BW38; and between CY and SW were greater than the estimates with BW7 and BW30, indicating that BW38 or SW could be a more suitable a selection than BW7 or BW30 for an indirect selection of $\mathrm{CY}$.

Phenotypic correlations between performance and carcass traits were positive and ranged from moderate to high. However, phenotypic correlations between LY and performance and carcass traits were low, except between LY and LW, in which the phenotypic correlation was high and positive, and LY and BRY where phenotypic correlation was moderate and negative (Table 3).

The correlated responses between BW30 and BW38 and carcass traits are presented in Figure 1 (A-B). Correlated responses obtained using $\mathrm{BW} 30$ as selection criteria for traits $\mathrm{CW}, \mathrm{BRW}$, and LW were 89.86, 35.13 and $31.24 \mathrm{~g}$, respectively.
A

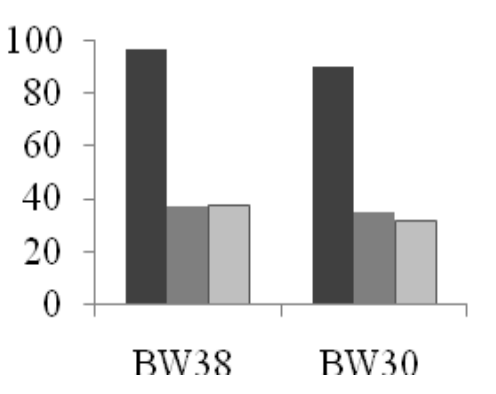

B

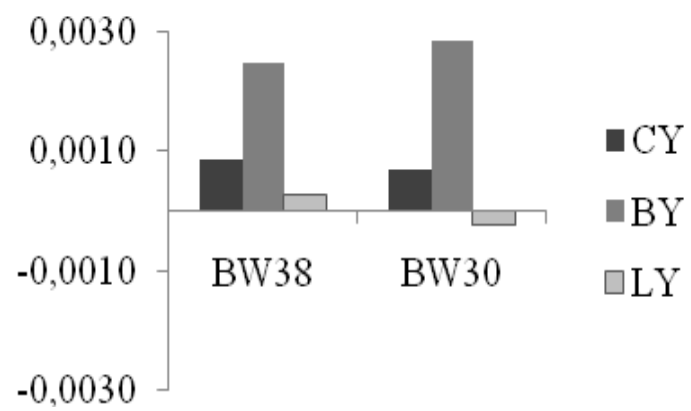

Figure 1. Correlated responses among carcass traits and body weights at 30 (BW30) and 38 days of age (BW38), where (A) carcass weight (ם), breast weight (ם) and leg weight $(\mathbf{\square})$, and (B) carcass yield ( $\mathbf{\square})$, breast yield ( $\mathbf{\square})$ and leg yield (

For BW30, similar responses were obtained for CW, BRW, and LW. This indicates that BW30 is more efficient than BW38 if used as selection criteria for $\mathrm{CW}, \mathrm{BRW}$ and $\mathrm{LW}$, since BW30 occurs earlier than BW38. The correlated responses obtained for $\mathrm{CY}$, BRY and LY using BW30 as selection criteria were lower and similar to responses obtained for BW38.

The genetic gain for CY, BRY and LY were higher than its correlated responses, indicating that the direct selection of these traits should be favored over the indirect selection through BW30 or BW38. Genetic trends estimates for BW7, BW30, BW38, and BW (Figure 2, A-D) were 7.56, 44.24, 76.41 and 10.47 g/generation, respectively. This indicates that these traits increased in the generations studied.

The genetic trend of SW was smaller than BW30 and BW38, maybe due to a pre-selection before slaughter, what may have occurred. For carcass traits are presented in Figure $3(\mathrm{~A}-\mathrm{F})$. The traits $\mathrm{CW}, \mathrm{BRW}$ and $\mathrm{LW}$ presented genetic trends of $11.76,6.58$ and 3.15 $\mathrm{g} /$ generation, respectively, indicating 
that these traits tend to increase in this population. These values are higher than those obtained by Grosso et al. (2009). Genetic trend obtained of CY was low (0.003). However, the heritability estimate of the CY was moderate (0.19), although the coefficient of variation was $1.28 \%$, indicating a low variability of this trait in this population and a low ability to selection response.

Estimates of genetic trends obtained for BRW and BRY were positive (Figure 3 ), indicating genetic gains of these

A

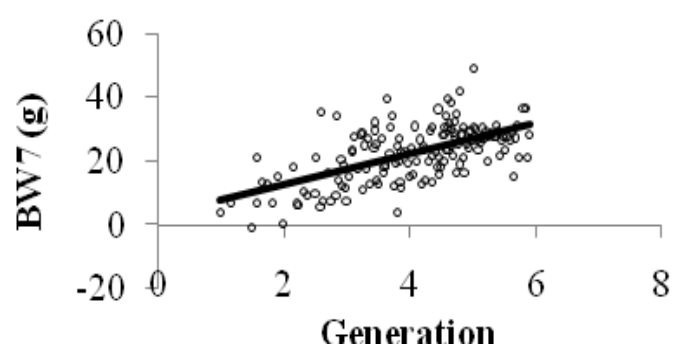

C

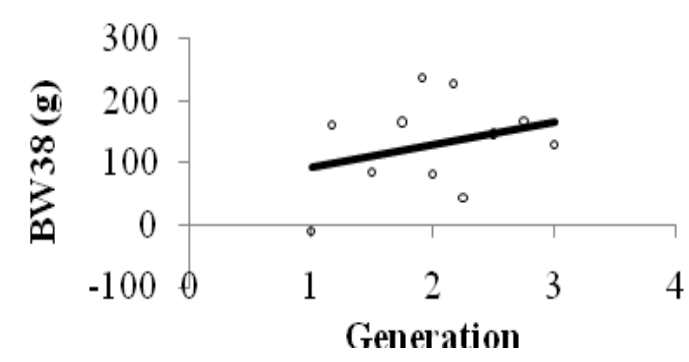

traits, and that the selection was present in this population. These results were smaller than Le Bihan-Duval et al. (1998) which reported genetic trends of $19.9 \mathrm{~g}$ e $0.75 \%$ to the traits BRW and BRY respectively. Genetic trends associated to performance and carcass traits indicated that selection of body, breast and leg weight has occurred. Genetic gains indicate the possibility of obtaining gains greater than the ones observed, depending on the adopted selection strategy.
B

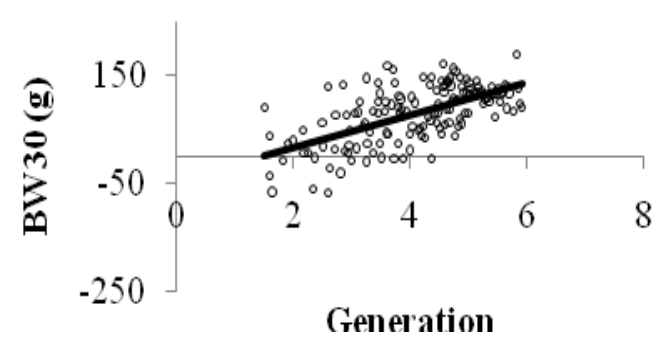

D

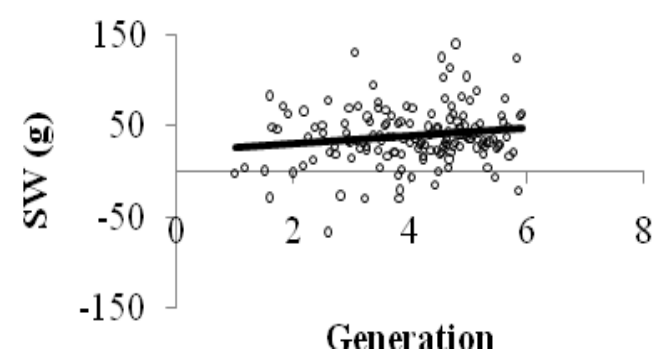

Figure 2. Genetic trends for body weight in a commercial line of broiler chicken, breeding values (O). A. Body weight at 7 days (BW7, $\beta=7.56(0.041)$; B. Body weight at $30 \mathrm{~d}$ (BW30, $\beta=44.24$ (0.466)); C. Body weight at 38 d. (BW38, $\beta=76.41$ (0.595)); D. Slaughter weight (SW, $\beta=10.47$ (0.237)) 
A

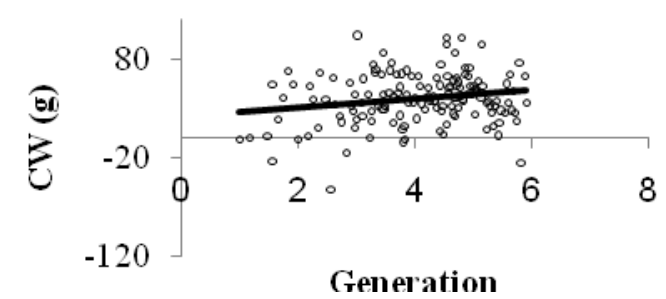

C

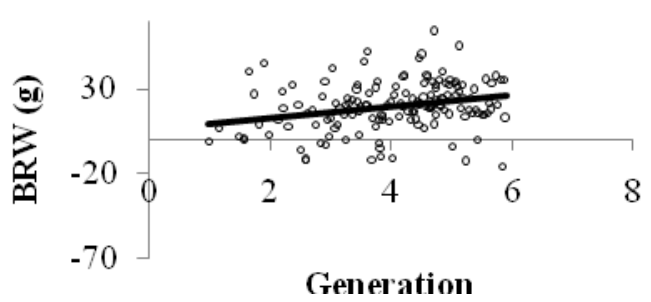

$\mathbf{E}$

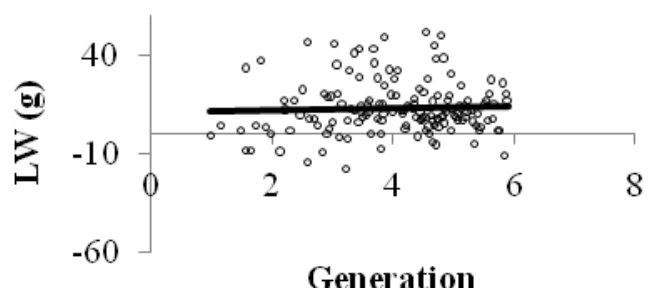

B

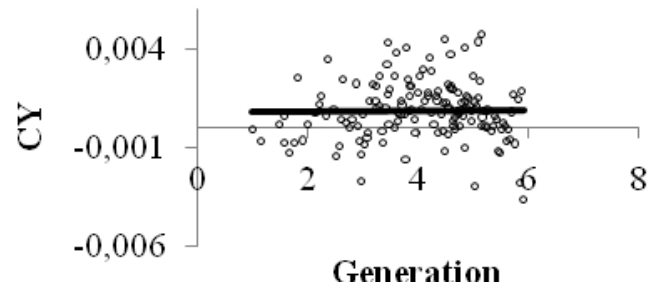

D

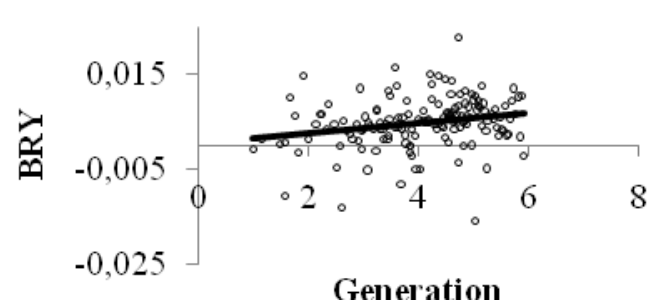

$\mathbf{F}$

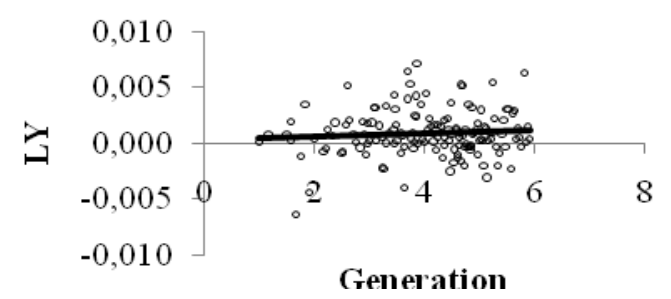

Figure 3. Genetic trends for carcass traits in a commercial line of broiler chicken, breeding values (O). A. Carcass weight ( $\mathrm{CW}, \beta=11.7 \mathrm{~g}(0.197)$ ); B. Carcass yield (CY, $\beta=0.0003(0.00001)$ ); C. Breast weight (BRW; $\beta=6.58(0.098)$ ); D. Breast yield (BRY, $\beta=0.0018$ (0.00003)); E. Leg weight (LW, $\beta=3.15$ (0.093)); F. Leg yield (LY, $\beta=0.00007(0.000017))$

The genetic correlations and potential correlated responses between body weight (at 30 or 38 days) and the breast and leg weight indicate the efficiency of the indirect selection of these carcass traits using body weight at 30 or 38 days of age. The selection at these ages might be used instead of the slaughter weight, as it anticipates selection in around 12 days.

\section{REFERENCES}

CARLBORG, O.; KERJE, S.;

SCHUTZ, K.; JACOBSSON, L.; JENSEN, P.; ANDERSSON, L. A global search reveals epistatic interaction between QTL for early growth in the chicken. Genome

Research, v.13, n.3, p.413-421, 2006. 
FANATICO, A.C.; PILLAI, P.B.; EMMERT, J.L.; OWENS, C.M. Meat quality of slow- and fast-growing chicken genotypes fed low nutrient or standard diets and raised indoors or with outdoor access. Poultry Science, v.86, n.10, p.2245-2255, 2007.

GAYA, L.G.; FERRAZ, J.B.S.; REZENDE, F.M.; MOURAO, G.B.; MATTOS, E.C.; ELER, J.P.; MICHELAN FILHO, T. Heritability and genetic correlation estimates for performance and carcass and body composition traits in a male broiler line. Poultry Science, v.85, n.5, p.837-843, 2006.

GILMOUR, A.R.; GOGEL, B.J.; CULLIS, B.R.; THOMPSON, R. ASReml User Guide Release 3.0. Hemel Hempstead, UK: VSN International Ltd, 2009. 398p.

GROSSO, J.; BALIEIRO, J.C.C.; ELER, J.P.; FERRAZ, J.B.S.; MATTOS, E.C.; MICHELAN FILHO, T. Comparison of different models to estimate genetic parameters for carcass traits in a commercial broiler line.

Genetics and Molecular Research, v.9, n.2, p.908-918, 2010.

GROSSO, J.; BALIEIRO, J.C.C.; ELER, J.P.; FERRAZ, J.B.S.;

MATTOS, E.C.; MICHELAN FILHO, T.; FELICIO, A.M.; REZENDE, F.M. Estimates of genetic trend for carcass traits in a commercial broiler line.

Genetics and Molecular Research, v.8, n.1, p.97-104, 2009.

HAVENSTEIN, G.B.; FERKET, P.R.; QURESHI, M.A. Growth, livability, and feed conversion of 1957 versus 2001 broilers when fed representative 1957 and 2001 broiler diets. Poultry Science, v.82, n.10, p.1500-1508, 2003.
Le BIHAN-DUVAL, E.; MIGNONGRASTEAU, S.; MILLET, N.; BEAUMONT, C. Genetic analysis of a selection experiment on increased body weight and breast muscle weight as well as on limited abdominal fat weight.

British Poultry Science, v.39, n.3, p.346353, 1998.

LE BIHAN-DUVAL, E.; BERRI, C.; BAEZA, E.; MILLET, N.;

BEAUMONT, C. Estimation of the genetic parameters of meat characteristics and of their genetic correlations with growth and body composition in an experimental broiler line. Poultry Science, v.80, n.7, p.839-843, 2001.

LÓPEZ, K.P.; SCHILLING, M.W.; CORZO, A. Broiler genetic strain and sex effects on meat characteristics. Poultry Science, v.90, n.5, p.1105-1111, 2011.

N'DRI, A.L.; MIGNON-GRASTEAU, S.; SELLIER, N.; TIXIER-BOICHARD, M.; BEAUMONT, C. Genetic relationships between feed conversion ratio, growth curve and body composition in slow-growing chickens. British

Poultry Science, v.47, n.3, p.273-280, 2006.

RANCE, K.A.; MCENTEE, G.M.; MCDEVITT, R.M. Genetic and phenotypic relationships between and within support and demand tissues in a single line of broiler chicken. British Poultry Science, v.43, n.4, p.518-527, 2002.

SEWALEM, A.; MORRICE, D.M.; LAW, A.; WINDSOR, D.; HALEY, C.S.; IKEOBI, C.O.N.; BURT, D.W.; HOCKING, P.M. Mapping of quantitative trait loci for body weight at three, six, and nine weeks of age in a broiler layer cross. Poultry Science, v.81, n.12, p.1775-1781, 2002. 
Rev. Bras. Saúde Prod. Anim., Salvador, v.15, n.4, p.1006-1016 out./dez., 2014 http://www.rbspa.ufba.br ISSN 15199940

VAYEGO, A.S.; DIONELLO, N.J.L.; FIGUEIREDO, E.A.P. Estimativas de parâmetros e tendências genéticas para algumas características de importância econômica em linhagem paterna de frangos de corte sob seleção. Revista Brasileira de Zootecnia, v.37, n.7, p.1230-1235, 2008.

YANG, N.; JIANG, R.S. Recent advances in breeding or quality chickens. World's Poultry Science Journal, v.61, p.373-381, 2005.

ZEREHDARAN, S.; VEREIJKEN, A.L.J.; VAN ARENDONK, J.A.M.; VAN DER ;WAAIJ, E.H. Estimation of genetic parameters for fat deposition and carcass traits in broilers. Poultry Science, v.83, n.4, p.521-525, 2004.

ZEREHDARAN, S.; VEREIJKEN, A.L.J.; VAN ARENDONK, J.A.M.; BOVENHUIS, H.; VAN DER WAAIJ, E.H. Broiler breeding strategies using indirect carcass measurements. Poultry Science, v.84, p.1214-1221, n.4, 2005.

Data de recebimento: $26 / 01 / 2014$

Data de aprovação: 19/11/2014 